\title{
Jak rozmawiać z uczniami online? Kształtowanie wartości moralnych na e-lekcjach języka polskiego
}

\section{How to communicate with students online? Shapening moral values during Polish e-learning lessons}

\author{
Aleksandra Araszkiewicz
Zespół Szkół w Mieście Obrzycko
ORCID: 0000-0001-6179-8384
}

\begin{abstract}
The author refers to experiences of distance learning, which has been introduced in Polish schools in March 2020. The author is also concerned about how moral values may be shaped and how to discuss with teenagers about serious topics in the new form of education. She presents proposals of literary works, which may be a base for further considerations (and discussion) during remote Polish literature classes in 7th and 8th grade. Texts have been grouped taking into account such values as: respect, responsibility, self-discipline (meant as development of self-potential and self-control), fairness, as well as friendship and love. To each of the lectures referred the author is presenting methods and forms of work with students. The change of teaching form stressed out the role of school in the modern world.
\end{abstract}

Key words: education, distance learning, moral values, the role of school

Streszczenie: Autorka odnosi się do doświadczeń nauczania na odległość, które zostało wprowadzone w polskich szkołach w marcu 2020 roku. Zastanawia się nad tym, jak w tej nowej formie edukacji można kształtować wartości moralne oraz jak można rozmawiać z nastolatkami na trudne tematy. Przedstawia propozycję utworów literackich, które można uczynić punktem odniesienia do namysłu (i dyskusji) na zdalnych lekcjach języka polskiego w klasach VII i VIII. Teksty zostały pogrupowane w obrębie takich wartości, jak: szacunek, odpowiedzialność, samodyscyplina (rozumiana jako rozwijanie własnego potencjału i samokontrola), sprawiedliwość, a także przyjaźń i miłość. Do każdej z zaproponowanych lektur autorka podaje metody i formy pracy z uczniami. Zmiana sposobu nauczania uwypukliła, jaka jest rola szkoły w nowoczesnym świecie.

Słowa kluczowe: edukacja, nauczanie zdalne, wartości moralne, rola szkoły

Końcowe miesiące roku szkolnego 2019/2020 sprawiły, że edukacja cyfrowa stała się standardem. Do niedawna dzieci i młodzież korzystały z urządzeń elektronicznych, jeśli tego chciały, a technologie komunikacyjne na lekcjach miały wspierać ich rozwój i edukację. Od marca 2020 roku stały się niemal wyłącznym narzędziem służącym do nauki, a ich używanie - obowiązkiem. 
W obliczu tej zmiany, która w zdecydowany sposób wpłynęła także na rozwój społeczny uczniów, warto zastanowić się, jak w nauczaniu na odległość należy kształtować wartości moralne oraz jak można rozmawiać z nastolatkami na trudne tematy, jak choroba, cierpienie i śmierć, dylematy egzystencjalne, miłość i erotyzm, poczucie wyobcowania i odtrącenia. Ostatnie miesiące pokazały, że trudno przewidzieć, jaką postać przybierze świat, jakie wyzwania przed nami postawi, jakie zaoferuje szanse. Właśnie dlatego niezwykle ważną kompetencją, umożliwiającą świadome funkcjonowanie w dorosłym życiu, jest rozumienie otaczającej rzeczywistości, wciąż ulegającej zmianom. W związku z tym należy kształcić i pogłębiać zarówno podstawową wiedzę o świecie ${ }^{1}$, jak i zdolność radzenia sobie z informacyjnym szumem ${ }^{2}$. Zapomina się jednak często, że mocny system wartości daje dziecku wsparcie i ochronę przed wieloma błędami, a także stanowi swego rodzaju życiowy drogowskaz.

To zadanie stało się $\mathrm{w}$ roku 2020 bardzo istotne $\mathrm{z}$ punktu widzenia nauczyciela, rodzica oraz ucznia. Wprowadzenie nauczania na odległość ujawniło, że uczniowie wykazują się zaskakującą wiedzą, odwagą w wyrażaniu poglądów, znajomością swoich praw, biegłością w operowaniu nowościami technologicznymi (aplikacjami, programami), a jednocześnie mają trudności z czytaniem, pisaniem, organizowanie warsztatu pracy i planowaniem. Wydawałoby się, że „cyfrowi tubylcy” (według określenia Marca Prensky'ego) powinni być o wiele bardziej zaawansowani w stosowaniu technologii informatycznej od nauczycieli. Tym bardziej więc zaskakiwały takie problemy, jak kłopoty z zalogowaniem się do odpowiedniej platformy (np. Zoom), odświeżeniem strony czy nawet sprawdzeniem wiadomości w dzienniku elektronicznym ${ }^{3}$. Choć znaleźli się uczniowie, którzy poradzili sobie świetnie, mam wrażenie, że większość miała jednak problem z odnalezieniem się w wirtualnej rzeczywistości.

Zmiana sposobu komunikacji między uczniem a nauczycielem $\mathrm{z}$ jednej strony obnażyła słabości systemu edukacji, nieprzygotowanego do nauczania zdalnego. $Z$ drugiej jednak pokazała, że w szkole liczą się przede wszystkim pozytywne relacje między uczonym a uczącym. Dzięki nim wzrasta motywacja ucznia do rozwijania się i zdobywania wiedzy, pobudza się go do wysiłku umysłowego, by jego celem było zrozumienie oraz poczucie sprawczości. Temu sprzyjają różnorodne metody pracy, jej atrakcyjne,

\footnotetext{
${ }^{1}$ Mam na myśli pewien zbiór sprawdzonych wiadomości, umiejętności, definicji tworzący siatkę pojęciową, dzięki której łatwiej jest odnaleźć się w rzeczywistości.

${ }_{2}$ Chodzi przede wszystkim o umiejętność przetwarzania informacji, analizy i syntezy, interpretowania ich, wyciągania wniosków i znajdowania analogii w codzienności.

3 Sabina Świtała $(2018,155)$ przywołała opracowany przez Rubena Puentedurę model SAMR, definiujący cztery poziomy integracji technologii w edukacji. W nauczaniu stacjonarnym komputer i Internet używane są do wykonywania tradycyjnych zadań (Substition - zastąpienie, podstawianie, poziom 1) lub do rozwiązywania podstawowych zadań, mających wzbudzać zainteresowanie uczniów (Augumentation - rozszerzenie, poziom 2). Technologia zatem jest dodatkiem, który ma zwiększyć atrakcyjność lekcji. Nauczanie zdalne natomiast wymaga przeniesienia się na poziomy: 3 (Modification - modyfikacja) oraz 4 (Redefinition - redefinicja). Z jednej strony technologia staje się konieczna do wykonania zadania, z drugiej pozwala na realizację złożonych działań uczniowskich. W każdym z tych dwóch przypadków wymaga się od użytkowników (nauczycieli i uczniów) wprawy w posługiwaniu się komputerem, umiejętności szukania informacji w Internecie i znajomości zasad netykiety.
} 
aktywizujące i niekonwencjonalne formy, pozwolenie na doświadczenie radości tworzenia, zainteresowanie opiniami, doświadczeniami i refleksjami uczniów.

Przede wszystkim jednak należy zadbać o zapewnienie poczucia bezpieczeństwa uczniom. Ten właśnie aspekt został wystawiony na próbę. Jako nauczycielka zastanawiałam się, jak rozmawiać o niepokojach, nadziejach i oczekiwaniach dzieci i młodzieży w sytuacji, gdy ograniczono ich życie pozaszkolne, gdy zgodnie z obowiązującymi przez kilka tygodni przepisami w Polsce nie wolno było im wyprowadzić psa, pójść do sklepu ani na spacer bez nadzoru osoby dorosłej, gdy nie mogli wyjść dokądkolwiek i spotkać się z kimkolwiek poza najbliższą rodziną. W wielu przypadkach prawdopodobnie zachwiało to ich poczuciem bezpieczeństwa, wolności i niezależności, spowodowało zagubienie, osamotnienie, odcięcie od towarzystwa, brak ruchu. Z drugiej strony długie przebywanie z członkami rodziny $\mathrm{w}$ niewielkich domach oraz wspólny pokój z rodzeństwem wpłynęły nie tylko na zwiększenie potrzeby intymności, ale zrodziły także dodatkowe niedogodności w pracy zdalnej. Należy także wspomnieć, że wiele rodzin borykało się z takimi problemami, jak zagrożenie zdrowia i utrata stabilności zawodowej oraz ograniczenie możliwości zarobkowania. Niełatwo było dzieciom w takiej sytuacji inicjować rozmowę o swoim złym samopoczuciu psychicznym.

W tej sytuacji w sukurs przyszła edukacja polonistyczna, która uczy czytania literatury i kultury, a przez nie - czytania samego siebie i otaczającego nas świata. Dzięki starannemu doborowi tekstów czytanych na lekcjach języka polskiego można było nie tylko wesprzeć uczniów, ale także kształtować wartości moralne. Warto pamiętać, że „uczniowie uczą się wtedy, gdy są aktywnie zaangażowani w prezentowanie zagadnienia i kiedy się nad nimi zastanawiają" (Black i in. 2006, 111). Dlatego zadaniem polonisty jest przekonanie ucznia, że on - jako czytelnik - jest ważny, że jego doświadczenia i refleksje stanowią istotny głos w interpretowaniu dzieła. „Przede wszystkim - słusznie stwierdziła Anna Janus-Sitarz (2009, 232) - ważna jest postawa nauczyciela - partnera i przewodnika, który inicjuje rozmowę o tekście i tworzy atmosferę sprzyjającą rozumieniu i porozumieniu". Do jego zadań należy staranne wybieranie lektury do szkolnej analizy, umiejętnie dostosowywanie strategii interpretacyjnych i tworzenie sytuacji dydaktycznych sprzyjających zwiększonej motywacji do lektury (Janus-Sitarz 2009, 234).

Wartości stanowią trudną i niejednoznaczną materię, której treść zależy od wielu czynników, w tym kontekstu historycznego i kulturowego. Dlatego w swoich rozważaniach proponuję teksty, które można uczynić punktem odniesienia do namysłu (i dyskusji w czasie lekcji języka polskiego online) nad takim wartościami, jak: szacunek, odpowiedzialność, samodyscyplina (rozumiana jako rozwijanie własnego potencjału i samokontrola), sprawiedliwość, a także przyjaźń i miłość. 


\section{Szacunek}

Jak wiadomo, „wychowanie w określonej kulturze lub w środowisku kierującym się ustalonymi zasadami programuje proces kształtowania się tożsamości nastolatka, wytycza mu cele, mobilizuje go lub pozbawia aspiracji i wsparcia" (Janus-Sitarz 2017, 11). W dużym stopniu wpływa na stosunek nastolatka do nauki, a przede wszystkim do czytania. Szukając tekstu poświęconego szacunkowi, warto pamiętać, że czytanie utworów literackich może być treningiem emocjonalnym, który pomoże dziecku - przez identyfikację z bohaterem/bohaterką - rozpoznać, nazwać i uporządkować emocje oraz ukaże różnorodność sposobów komunikacji w kontaktach z innymi ludźmi.

W ubiegłym roku przeczytałam entuzjastyczną recenzję książki Pasztety, do boju! Clementine Beauvais (2017), co skłoniło mnie do przeczytania tej powieści. Główna bohaterka, piętnastoletnia Mireille Laplanche, zdobywa tytuł Brązowego Paszteta w konkursie na najbrzydszą dziewczynę w szkole, zorganizowanym przez jej dawnego przyjaciela, Malo. Dziewczyna poznaje pozostałe laureatki, Hakimę i Astrid. Postanawiają wspólnie wyruszyć latem rowerami z rodzinnego Bourg-en-Bresse do Paryża. Każda ma określony cel, dla którego podejmuje się wyprawy. Towarzyszy im niepełnosprawny były żołnierz, brat Hakimy, Kader, a w czasie podróży sprzedają paszteciki. Swoją działalnością zyskują niemałą popularność w mediach, a także muszą zmierzyć się z internetowym hejtem oraz podstępami Malo. Po tygodniu docierają do Paryża. Dojrzewają, nabierają dystansu do siebie i innych, akceptują siebie takimi, jakie są.

Lekcja wprowadzająca opiera się na tekście literackim, jego bohaterach, świecie przedstawionym, rozwiązaniach fabularnych. Dlatego warto zacząć pracę z tym tekstem (np. w czasie spotkania online) od postawienia uczniom pytań: Co dało Ci przeczytanie tej książki? Czego dowiedziałeś się / dowiedziałaś się o sobie i innym człowieku? Czy coś Cię zaskoczyło, zdziwiło? Jeśli tak, to co? Jeśli nie, to dlaczego? Czy opisana sytuacja jest Ci bliska / znana? Jak Ty byś sobie poradził / poradziła na miejscu „pasztetów”? Co ten tekst mówi o współczesnych nastolatkach? Z jakimi przemyśleniami Ciebie zostawia? Prowadzenie dialogu powinno być jednocześnie swoistą wędrówką wśród znaczeń, jakie niesie tekst. W ten sposób uczeń zrozumie tekst głębiej

W trakcie kolejnej lekcji skupiamy się na analizie wpisów internetowych oraz medialnych na temat pasztetów, które w swojej narracji często przytacza Mireille. Zwracamy uwagę na ich rozbieżność - od zachwytu do dosadnej krytyki. Ponownie zachęcamy uczniów do postawienia się w sytuacji dziewcząt. W początkowej fazie ważne jest zaangażowanie emocjonalne, które pozwoli nastolatkom postawić się w roli bohaterów, odczytać

${ }^{4}$ Warto także zaprezentować na początku omawiania lektury fragmenty krytyki nieprofesjonalnej w blogach, np. Bardziej lubię książki, Ciut więcej, Dżin z tomikiem, W Nieparyżu itp. W ten sposób uczeń konfrontuje swoją opinię z uwagami innych, a także rozwija się jako refleksyjny czytelnik. 
znaczenia ich działań, zrozumieć intencje. Jak czułbym się / czułabym się, zwyciężając w konkursie brzydoty? Dlaczego łatwiej krytykować niż chwalić? Dlaczego ludziom łatwiej jest ranić innych przez Internet niż prosto w oczy? Można również poprosić o odniesienie się do stwierdzenie Mireille, że „taka przepaść jest między wpisami internetowymi a ludźmi, których spotykamy" (Beauvais 2017, 199). Uczniowie mogliby się zastanowić także, czym jest szacunek i jak można go okazać innym, różniącym się od nas, a wnioski przedstawić na forum całej klasy.

Aby jednak tekst stał się źródłem nowych doświadczeń poznawczych, społecznych i emocjonalnych, w dialogu na jego temat muszą aktywnie wziąć udział wszyscy, najlepiej w mniejszych zespołach, by zaangażować uczniów o różnym poziomie kompetencji, zróżnicowanych doświadczeniach i zainteresowaniach. W przypadku nauczania zdalnego musiałam znaleźć inne rozwiązanie. Dialog jest oparty na współpracy i współdziałaniu, uczy empatii i szacunku, gotowości do pomocy i odpowiedzialności za to, co się mówi i robi. Niektóre programy i aplikacje dają taką możliwość, w tym między innymi używany w mojej szkole do komunikacji z uczniami Zoom.

Uczniowie zostają podzieleni i umieszczeni w tak zwanym „pokojach” (nauczyciel ma możliwość podglądu, co się dzieje w tych grupach). Każda grupa otrzymuje polecenie omówienia innego sposobu okazywania szacunku, między innymi: grzeczności, troski o dobro i uczucia innych, poszanowania ich godności, zaspokajania potrzeb innych, poszanowania odmienności, dotrzymywania słowa, dbałości o dobre imię. Analizie trzeba poddać nie tylko stosunek Malo (i innych hejterów) do „pasztetów”, bohaterek wobec siebie, ale także Mireille do matki i ojczyma. Można zastanowić się nad zasadnością stwierdzenia narratorki, że „brzydkim może się nie wieść, są brzydcy" (Beauvais 2017, 199). Następnie warto, aby uczniowie wymienili się spostrzeżeniami. Czytanie tego tekstu wymaga postawienia wielu pytań: o różne punkty widzenia, o różnorodne interpretacje; pytań otwartych, budzących zaciekawienie, zachęcających do namysłu i do określenia strategii szukania odpowiedzi, do działania twórczego; pytań odwołujących się do wiedzy dziecka, jego doświadczeń (jednocześnie szanujących prywatność ucznia, jego wrażliwość).

Dalszą część zajęć proponuję poświęcić analizie, interpretacji i ocenie intencji, zachowań, wyborów poszczególnych postaci, dzięki czemu otrzymamy mozaikę różnych punktów widzenia rzeczywistości (nie tylko uczestników rowerowej wyprawy, ale także ich rodziców, a nawet czarnego charakteru tej powieści - Malo). Ponadto należałoby przeanalizować język, którym posługuje się główna bohaterka i jednocześnie narratorka powieści, gdyż uczniowie nie zawsze zdają sobie sprawę, jak bardzo język określa człowieka. Chodzi zarówno o zastosowane słownictwo, jak i o stopień przestrzegania poprawności gramatycznej. W tekście pada wiele określeń typowych dla gwary młodzieżowej, Mireille wypowiada się w specyficzny sposób, zrozumiały dla ogółu, a jednak charakterystyczny dla swojej grupy 
wiekowej. Warto zwrócić uwagę, że dystans do siebie odzwierciedla się nie tylko w jej postawie, ale i w sposobie wypowiadania się, co widać także w sposobie łączenia zdań i przechodzenia między wątkami.

\title{
Odpowiedzialność
}

Czy jest nauczyciel, który nie chciałby, by jego uczniowie rzetelnie wypełniali swe obowiązki, dotrzymywali słowa, byli punktualni, zapobiegali złu, a także ponosili konsekwencje swoich decyzji i zachowań? Zapewne każdy o tym marzy, jednak należy pamiętać, że odpowiedzialności dzieci uczą się na ogół od dorosłych, obserwując ich w codziennym życiu. Dlatego warto pokazać uczniom bohatera dziecięcego, który był odpowiedzialny nie tylko za siebie, swoje myśli, wybory i czyny, ale także za inną osobę, związaną z nim, przebywającą pod jego opieką.

Mały Książę A. de Saint-Exupery'ego jest lekturą obowiązkową dla klas VII-VIII, jedną z bardziej lubianych przez uczniów. Chodzi nie tylko o bohatera traktowanego jak dziecko, choć zachowującego się nie bardzo dziecięco. Młodych czytelników urzekają lakoniczny język oraz sentencje, a otwarte zakończenie utworu zachęca do snucia ciągu dalszego. Poza tym motywy związane z tym dziełem pojawiają się $\mathrm{w}$ filmie, reklamie, a nawet na muralu na jednej z poznańskich kamienic ${ }^{5}$. Mały Książę pomaga nastolatkom znaleźć zakorzenienie w kulturze. Pozwala konstruować tożsamość kulturową, porozumieć się z ludźmi wychowanymi w jednej kulturze, wzmacnia więzi międzypokoleniowe. Utwór realizuje to, co o kanonie lektur napisała Ewa Nowak $(2007,29)$ :

\begin{abstract}
Istnieje przekonanie o trwałej potrzebie istnienia w życiu społecznym kanonu, rozumianego jako zbiór utworów literackich powszechnie uznanych za wartościowe. Podtrzymuje on zbiorową pamięć, jest nośnikiem tradycji, bez której społeczność nie mogłaby trwać i rozwijać się, konstytuuje związki między jednostkami zakorzenionymi w tym samym obszarze swojskości. Utwory z kanonu utrwalają i przekazują wartości, których dziedziczenie przez kolejne pokolenia gwarantuje istnienie zbiorowej tożsamości.
\end{abstract}

Z drugiej strony można wykorzystać utwór, aby wspomóc ucznia w zmaganiu się z kwestiami bieżącymi. Główny bohater, zadając najprostsze pytania, stara się odkrywać motywacje działań rozmówcy: „Dlaczego? Czego szukasz? Po co? Kim jesteś? Co to znaczy?”. Tego typu pytania skłaniają do refleksji, do zatrzymania się. Uczniowie, zanurzeni w technologii, są bombardowani doniesieniami, zasypywani tekstami, zalewani interpretacjami. W ich gąszczu nietrudno o zagubienie. Bywają więc bezradni, nie wiedząc, w co wierzyć, co traktować jako pewnik, w czym pokładać ufność. W czasie izolacji Internet zalała fala fake newsów związanych z koronawirusem. Dla nastolatków wielkim wyzwaniem było właściwe filtrowanie informacji, odsiewanie rzetelnych od błędnych. Aby nie dać się zwieść fałszywym

5 Zob. https://bi.im-g.pl//m/0a/01/18/z25173514V,Mural-z-Malym-Ksieciem-przy-ul--Ogrodowej-5-w-Pozn.jpg (dostęp: 18.10.2020). 
informacjom, potrzebna jest postawa krytyczna, rozumiana jako chęć i zdolność do zgłębiania, podważania i weryfikowania zewnętrznych przekazów, a przykład takiej postawy jest właściwy właśnie Małemu Księciu i wyraża się w stawianych przez niego pytaniach.

Jako ćwiczenie wprowadzające do tematu odpowiedzialności warto wykorzystać przezroczyste naczynie (na przykład słoik), kilka większych i mniejszych kamieni (oznaczających obowiązki) oraz piasek (symbolizujący zabawę, przyjemności). Tymi akcesoriami może dysponować tylko nauczyciel lub każdy z uczniów. Eksperymentujący musi znaleźć sposób, by zmieścić w naczyniu jak najwięcej elementów. Jeśli zacznie od przyjemności, nie uda mu się zmieścić obowiązków. Jeśli natomiast zacznie od największych kamieni, puste przestrzenie wypełni mniejszymi kamykami i piaskiem. Wynik eksperymentu powinien skłonić uczniów do zastanowienia się nad ewentualnymi skutkami odkładania obowiązków na potem oraz skutkami przedkładania przyjemności nad obowiązki.

Odpowiedzialność Małego Księcia można pokazać w formie pokoju zagadek, utworzonego dzięki programowi Genially (Genial.ly), który umożliwia tworzenie animowanych i interaktywnych prezentacji. Zadanie nauczyciela polega na przygotowaniu serii slajdów zawierających polecenia lub pytania, a poprawne ich wykonanie przez uczniów nagradzane jest zdobywaniem poszczególnych cyfr kodu potrzebnego do otwarcia sejfu. Zaczyna się od przedstawienia misji („Mały Książę zagubił się. Pomóż mu znaleźć mapę, dzięki której wróci na swoją planetę”). Planety, które odwiedził bohater, będą tłem dla kolejnych zadań. Odpowiedzi błędne wymagają korekty, poprawne - nagradzane są otrzymaniem cyfry i przejściem do następnego polecenia. Polecenia powinny nie tylko sprawdzać znajomość tekstu, ale przede wszystkim mają ukazać odpowiedzialne zachowanie Małego Księcia. Zatem należy uwzględnić zarówno rozkład dnia bohatera na swojej planecie, a zwłaszcza obowiązkowe czyszczenie wulkanów oraz pielenie baobabów, jak i ewentualne skutki zaniedbania tych obowiązków (np. zniszczenie planety, utrata ważnego dla siebie miejsca).

Ponadto należy pamiętać, że odpowiedzialność - jako cnota - ma różne aspekty: Mały Książę powinien dbać o Różę, być wobec niej wyrozumiały, bo był z nią związany, ale także dlatego, że sprawował nad nią opiekę. Chłopiec powinien także zadbać o siebie samego: o właściwy sposób komunikowania się z innymi, o własne szczęście ${ }^{6}$, własny rozwój i o kształtowanie swego charakteru. Po wykonaniu wszystkich zadań uczniowie są przenoszeni do slajdu ze skrzynią lub sejfem. Aby zakończyć misję, muszą wpisać poprawny kod.

${ }^{6}$ W czasie rozmowy o tym bohaterze warto podjąć również temat nieuchronności śmierci, choć niekoniecznie za pomocą prezentacji interaktywnej. O ile większości uczniów nie zastanawia obraz słonia konającego we wnętrznościach węża, o tyle często dociekają, jak należy rozumieć zakończenie - dlaczego Mały Książę musiał dać się ukąsić, dlaczego nie znalazł innego wyjścia (choćby znów wędrownych ptaków), czy wrócił na swoją planetę, jakie są jego dalsze losy (czyli co nas czeka po śmierci). O jego odejściu rzadko mówi się „samobójstwo”, a przecież dylematy egzystencjalne, które doprowadziły Małego Księcia do podjęcia takiej decyzji, nie są nastolatkom obce. 
Zabawa typu escape room, choć dla nauczyciela czaso- i pracochłonna, angażuje uczniów i z pewnością uatrakcyjnia lekcję (nie tylko) online. Poza tym możliwość nieograniczonego korygowania swoich błędów sprawia, że utrwalenie wiadomości przebiega w sposób bezstresowy.

\section{Samodyscyplina}

„Wdrażanie do samodzielnej pracy - stwierdziły Anna Janus-Sitarz i Ewa Nowak $(2012,129)$ - rozpoczyna się od organizowania własnego warsztatu pracy, nauki korzystania z dostępnych źródeł wiedzy". Problem tkwi w tym, że uczniowie nie potrafią zarządzać swoim czasem, nie potrafią się uczyć, bo nikt ich tego naprawdę nie uczył. W szkole otrzymują gotowe schematy, podpowiedzi, ich błędy są krytykowane i nie służą odnalezieniu rozwiązań. Janus-Sitarz zwróciła uwagę, że to pokolenie jest „przyzwyczajone do niezwykle szybkiego tempa życia, wraz z towarzyszącymi tej szybkości pozytywnymi i negatywnymi konsekwencjami. Młodzi ludzie odrzucają wszystko, co wymaga systematyczności i dłuższej pracy. Nie potrafią się skupić na jednym temacie (...) Nie dostrzegają niczego niemoralnego w wykorzystywaniu cudzych tekstów (zasada "wytnij i wklej»)" (Janus-Sitarz, Nowak 2009, 88). Tymczasem są to kompetencje niezbędne, by odnaleźć się w dorosłym życiu.

W chwili zamknięcia szkół zmuszono uczniów do całkowitej zmiany zachowań i przyzwyczajeń. W tej sytuacji szczególnie ważne były działania pedagogów. Warto pamiętać, że:

zadaniem nauczyciela jest ułatwić uczniowi rozsądne korzystanie z różnych źródeł wiedzy, pomóc mu w selekcjonowaniu informacji, w hierarchizowaniu otaczających go wartości. Przygotowanie młodych ludzi do samodzielnego zdobywania wiedzy musi polegać na wykształceniu postawy otwarcia na rzeczywistość i ciekawości świata, ale przy jednoczesnej umiejętności dokonywania wyboru przekaźników informacji, zdolności oceniania jakości i przydatności tych informacji (Janus-Sitarz, Nowak 2012, 122) .

Nie jest to zadanie łatwe do zrealizowania podczas nauki zdalnej. Nauczyciel powinien być świadomy zróżnicowanych doświadczeń swoich uczniów oraz ich kompetencji, zwłaszcza w zakresie czytania ze zrozumieniem. Należało z jednej strony odwoływać się do tych doświadczeń, z drugiej poszerzać je, ukazując korzyści płynące z rozwijania własnego potencjału i samokontroli.

Dobrym sposobem na zrealizowanie tych założeń jest według mnie przedstawienie uczniom postaci, która musiała wykazać się umiejętnością planowania, wytrwałością, silną wolą, motywacją i samokontrolą. W klasie VII omawia się - jako lekturę obowiązkową - Śmierć Pułkownika Adama Mickiewicza. Warto pokazać, że Emilia Plater nie była ani jedyną, ani najsławniejszą kobietą walczącą o niepodległość Polski w XIX w. Ponadto, choć o kobietach w historii mówi się coraz więcej, ich obecność na kartach 
szkolnych podręczników (i w świadomości uczniów) wciąż jest niemal niezauważalna? ${ }^{7}$.

Dlatego zaproponowałam fragmenty rozdziału Wojna i bunt z publikacji popularnonaukowej Brakująca połowa dziejów. Krótka historia kobiet na ziemiach polskich Anny Kowalczyk (Kowalczyk 2018, 263-285) z ilustracjami Marty Frej ${ }^{8}$. Dzięki tej pozycji młodzież przekonuje się, jak wiele zależy od czasu, w którym żyjemy, od warunków i ludzi, wśród których wzrastamy. Te czynniki mają ogromny wpływ na rozwijanie własnego potencjału i samokontroli. Praca z tym tekstem ułatwi pokazanie uczniom zalet czytania, sprawia, że więcej wiemy. Książka ta jest ważnym źródłem wiedzy, rzetelnie opracowanym, atrakcyjnie podającym informacje (staranny, ciekawy poziom graficzny i edytorski). Autorka opisuje różne formy kobiecej działalności w XIX w., wspomina o markietankach, micie Matki Polki, amazonkach i samarytankach, wywiadowczyniach, lekarkach, kadetkach, agitatorkach na rzecz wstępowania do wojska, pielęgniarkach, działaczkach Towarzystwa Dobroczynności Patriotycznej Warszawianek, Entuzjastkach, konspiratorkach, sybiraczkach, członkiniach Organizacji Bojowej i wielu innych. Uczniowie na ogół reagują zaskoczeniem, że Kowalczyk pisze o licznych kobietach, o których zapomniano.

Brakujaca połowa dziejów napisana jest przystępnym językiem, nie za trudnym, ale jednocześnie wymagającym skupienia. Dzięki analizie tego utworu uczniowie rozwijają kompetencje językowe i komunikacyjne, kształtują umiejętność wyrażania myśli, uczuć, emocji i ocen, tworzenia narracji o zdarzeniach. Każda z grup wybiera określone zadanie (przedstawienie fragmentu, historii grupy kobiet lub jednostki), planuje swoje działania, wyszukuje informacje i przedstawia je w określonej, atrakcyjnej dla siebie formie, przykładowo takiej, jak: chmura wyrazów (Tagxedo, Tagul Wordle), schematy i grafy (Easel.ly) oraz mapy myśli (Mindomo, Miro, Canva). Postaci kobiece wspomniane w tekście można przeanalizować ze szczególnym uwzględnieniem ich przygotowania do działalności bojowej i skutków ich zachowań, a następnie w formie notatek umieścić na wirtualnej tablicy (Padlet, Linoit). Można streścić tekst w prezentacji (Prezi, PowerPoint). Pracę ułatwi zmobilizowanie uczniów do pracy grupowej, w chmurze. W ten sposób będą uczyć innych i uczyć się od innych.

Jeśli dysponujemy czasem, warto byłoby poświęcić uwagę Aleksandrze Szczerbińskiej. Na przykładzie historii jej życia można przeanalizować, jaki wpływ na nasze życie mają takie kwestie, jak: zdolność zdobywania wiedzy, inteligencja, wyobraźnia, warunki fizyczne, uzdolnienia, środowisko, w którym wzrastamy. Po zakończeniu lekcji online uczniowie powinni być

7 Ponadto postać Emilii Plater poznają za pośrednictwem literackiej wizji poety, który nie tyle dbał o zgodność z faktami, ile o wywołanie odpowiedniego wrażenia u czytelników.

${ }^{8}$ Innym tekstem, który można wykorzystać w czasie lekcji, jest rozdział Henryka Pustowójtówna - dziewczyna z powstania z książki Anny Dziewit-Meller Damy, dziewuchy, dziewczyny. Historia w spódnicy z ilustracjami Joanny Rusinek (2017, 7-17). W przypadku tego utworu zwraca uwagę zastosowanie narracji pierwszoosobowej. Uczniowie mogą zastanowić się, w jaki sposób konstruuje się opowieść w imieniu postaci historycznej, jak z różnych źródeł tworzy się bohaterkę literacką. 
przekonani, że każdy ma jakieś talenty i zdolności, ale trzeba je odkryć i pielęgnować. Przekraczanie ograniczeń i przesuwanie granic swoich możliwości jest jednocześnie środkiem i skutkiem rozwijania samodyscypliny.

\section{Sprawiedliwość}

„Trzeba było ją sądzić po czynach, a nie po słowach” - powiedział Mały Książę do Pilota (Exupery 2019, 25), czując się odpowiedzialnym za swoją Różę. Sprawiedliwe traktowanie innych nie jest łatwe w żadnym wieku. Poza tym, nawet jeśli staramy się kierować zasadą obiektywizmu i dobrej woli, może znaleźć się ktoś, kto będzie się czuł pokrzywdzony, a nasze postępowanie uzna za niesprawiedliwe. Wtedy zamiast zadowolenia, szacunku do osoby oceniającej i chęci do pracy będziemy mieli do czynienia z poczuciem krzywdy, gniewem, buntem oraz frustracją.

Uczniom bardzo trudno zdefiniować, czym jest sprawiedliwość (zdecydowanie łatwiej wskazują przejawy niesprawiedliwości). Często łączą tę wartość z zasadą równości, rzadziej z poszanowaniem prawdy, przyzwoitym postępowaniem wobec innych czy właściwą oceną. Nie zawsze są też świadomi, że w sprawiedliwości zawierają się także inne wartości: uczciwość, odpowiedzialność, mądrość, odwaga, szacunek. Należy podkreślić społeczny charakter tej cnoty, zależnej od okoliczności i dokonującej się pomiędzy ludźmi.

Rozmowę na temat sprawiedliwości dobrze jest zacząć od przeczytania uczniom krótkiej bajki Michela Piquemala Sprawiedliwy podział (Piquemal 2012 , 33). Dwaj bracia spierali się o podział majątku po śmierci ich ojca. Gdy nie udało im się zawrzeć ugody, zwrócili się do mędrca z prośbą o radę. Ten im odpowiedział, że starszy brat ma podzielić, a młodszy jako pierwszy wybrać. Dzięki temu pomysłowi gwarantowany jest najbardziej sprawiedliwy podział - jeśli starszy brat podzieliłby majątek nierówno, młodszy, wybierając jako pierwszy, weźmie część „lepszą”. Prostota rozwiązania jest zaskakująca (nie tylko) dla uczniów. Po przeczytaniu utworu warto wrócić do definicji sprawiedliwości - czy coś należy dodać, a może coś zmodyfikować? Czy bohaterowie czują się usatysfakcjonowani? Czy rada była przydatna?

Można także sięgnąć po mity greckie, w których kwestia sprawiedliwości jest bardziej złożona, bo zakłada niezbywalną nierówność między śmiertelnikami a nieśmiertelnymi ${ }^{9}$. Bez względu na to, czy przypomnimy mit o Arachne, Marsjaszu lub o Akteonie, chodzi o to, że czytanie pozwala lepiej zrozumieć siebie, innych ludzi. Różne narracje literackie o losach bohaterów zachęcają do stawiania pytań o ocenę racji i wyborów dokonanych przez bohaterów, o sens ich życia, etyczną wartość motywacji oraz

\footnotetext{
${ }^{9}$ Omawiając mity, warto pamiętać, że współczesny uczeń - odbiorca kultury masowej, zanim zetknie się z mitem i jego kulturowymi reinterpretacjami, częstokroć poznaje najpierw formy mitopodobne. Na dostęp wszystkich do kultury i tego skutki zwróciła uwagę Marta Rusek $(2007,195-$ 196): „Dla polonisty oznacza to, posłużmy się najoczywistszymi przykładami, iż wiele opowieści literackich znanych jest uczniom wpierw $\mathrm{z}$ adaptacji filmowych, a dopiero później następuje - o ile następuje - konfrontacja filmu z jego literackim pierwowzorem".
} 
zachowań. Umiejętność antycypacji zdarzeń i konsekwencji wyborów dokonanych przez bohaterów literackich rozwija inteligencję, uczy wyczucia społecznego, wspomaga intuicję.

Jak już wspomniałam, kwestia sprawiedliwości w mitologii greckiej jest złożona. Ukaranie Arachne nie wydaje się uczniom adekwatne do „winy” - okazała się w końcu lepsza od swojej rywalki. Jednocześnie wskazać należy, że w tym świecie prawodawcami i strażnikami ładu moralnego są bogowie. Zestawienie kilku mitów dotyczących wykroczeń ludzi wobec porządku ustanowionego przez nieśmiertelnych pozwoli na pokazanie różnych znaczeń słowa „sprawiedliwość”.

Zarówno bajki Piquemala, jak i mity są utworami niewielkich rozmiarów i pozbawione szczegółów, uczniowie mogą znaleźć w nich cząstkę własnej biografii i swoje doświadczenia. Teksty ukazują problem egzystencjalny w sposób prosty i zwarty, a bohaterowie reprezentują określone typy. W przypadku kształtowania poczucia sprawiedliwości teksty literackie stanowią wprowadzenie do rozważań.

Aby przejść do głównej części zajęć poświęconych sprawiedliwości, należy przypomnieć, że jednym z jej aspektów jest równość wobec prawa. Zadaniem uczniów będzie stworzenie kodeksu postępowania wklasie/szkole. Jeśli grupa jest zżyta i jej członkowie dobrze się rozumieją, warto wykorzystać jedną z wirtualnych tablic współdzielonych (Whiteboard, Limnu).

Jeśli natomiast uczniowie mogą czuć się niekomfortowo lub jeśli chcemy wszystkich zmobilizować do składania propozycji zasad, można zastosować internetowe narzędzie do tworzenia tablic dla nauczycieli i ich całych klas, w której każdy z uczniów będzie dysponował swoją tablicą (Whiteboard.fi). Wszyscy pracują samodzielnie, nie widząc rozwiązań pozostałych członków klasy. Ten sposób umożliwia jednoczesne uzyskanie odpowiedzi od wszystkich uczniów na pytanie zadane przez nauczyciela.

Po zakończeniu składania propozycji należy je omówić, określić wspólnie ich ważność i ułożyć hierarchicznie. W ten sposób nie tylko słuchamy głosu naszych uczniów, ale także dowiadujemy się, co jest dla nich istotne w szkolnym współżyciu. Dobrze by było ten kodeks wydrukować i zawiesić w sali lekcyjnej, aby dzieci przekonały się po powrocie do szkoły, że to nie było tylko ćwiczenie.

\section{Przyjaźń i miłość}

Uczniowie muszą mieć świadomość, że otwierając książkę, jednocześnie rozpoczynają dialog z tekstem, że ich głos jest ważny, bo dotyczy doświadczenia jednostkowego, indywidualnego, że mają prawo odrzucić to, co przekazuje im autor / narrator / bohater. Dlatego namysł nad przyjaźnią i miłością warto powiązać z myśleniem filozoficznym i otworzyć tym samym uczniów na pogłębioną refleksję. Czytanie literatury i dialog z proponowanymi dalej tekstami można połączyć z kolei z zachętą do działań 
twórczych. Dlatego proponuję, by zajęcia rozpocząć od tego, by dzieci narysowały, czym są dla nich uczucia ${ }^{10}$. Pokazanie prac plastycznych stanie się wprowadzeniem do tematu lekcji: Czym dla mnie są miłość i przyjaźń?

Należy zwrócić uwagę, że przyjaźń łączy się z takim wartościami, jak: akceptacja, zaufanie, dyskrecja, szczerość, uczciwość, gotowość do udzielenia i przyjęcia pomocy, oddanie i lojalność. Jeśli natomiast chodzi o miłość, to istnieje wiele jej rodzajów. Definiowanie tych pojęć ze szczególnym naciskiem na indywidualne doświadczenie sprawi, że uczniowie dokonają autorefleksji, a pod wpływem wysłuchania innych - być może zrewidują własne przekonania. W osiągnięciu tego celu pomogą trzy niewielkich rozmiarów książki: Uczucia. Co to takiego? Oscara Brenifiera z cyklu Dzieci filozofuja (2017) oraz Przyjaźń i Miłość Astrid Desbordes (2016, 2019).

Pierwszy z wymienionych utworów składa się z serii pytań otwartych, pogrupowanych w kategorie: Dowody miłości (Skąd wiesz, że rodzice Cię kochaja?), Zazdrość (Czy jesteś zazdrosny o swoich braci i siostry?), Konflikt (Dlaczego kłócisz się z tymi, których kochasz?), Miłość (Czy dobrze jest być zakochanym?), Przyjaźń (Czy wolisz być sam, czy z przyjaciółmi?) i Nieśmiałość (Czy boisz się wypowiadać przed cała klasa?). Zadaniem uczniów jest odpowiedzenie na te pytania z krótkim uzasadnieniem. Następnie nauczyciel czyta wybrane wypowiedzi (na przykład do pierwszej kategorii: „Bo mnie całują”) oraz dodatkowe, pogłębiające pytania, na które odpowiada się już tylko w myślach.

W nauczaniu zdalnym kontakt twarzą w twarz jest znacznie utrudniony i - co za tym idzie - poczucie bezpieczeństwa i zaufanie bardziej kruche, dlatego warto ograniczyć dyskusję do kategorii miłości i przyjaźni ${ }^{11}$. W czasie lekcji online można wykorzystać wspomniane już wirtualne tablice - uczniowie piszą odpowiedzi, widzi je tylko nauczyciel. Jeśli ktoś chce, może się dodatkowo wypowiedzieć. Dobrym pomysłem jest też przygotowanie na podstawie tej publikacji quizu w Genially lub Nearpod. Dzięki tym narzędziom można zamieścić wszystkie treści potrzebne do przeprowadzenia lekcji w obrębie jednej prezentacji: filmy, teksty, polecenia dla uczniów, dokumenty, nagrania audio, linki do zewnętrznych zasobów. Atrakcyjnie wizualnie materiały interaktywne zachęcają do nauki. Dzięki takim prezentacjom treść zajęć jest uporządkowana i czytelna, a uczniowie mogą odkrywać nowe zasoby.

Dwie książki Astrid Desbordes zachwycają ilustracjami Pauline Martin oraz krótkimi zdaniami, podobnymi do sentencji ${ }^{12}$. W Miłości matka odpowiada na pytanie syna, Archibalda, czy będzie kochać go całe życie:

\footnotetext{
${ }^{10}$ Alternatywnym wprowadzeniem może być wybór cytatu na temat przyjaźni/miłości i prośba o uzasadnienie swojego wyboru.

${ }^{11}$ Kilka lat temu poświęciłam szereg lekcji do dyspozycji wychowawcy na rozmowę o uczuciach z klasą szóstą; siedzieliśmy w kręgu, uczniowie zapisywali odpowiedzi na kartkach i po ich twarzach mogłam się zorientować, jak poprowadzić dyskusję. Prowadzenie lekcji online jest pod wieloma względami trudniejsze niż spotkanie bezpośrednie.

${ }_{12}$ Teksty z języka francuskiego przełożył Paweł Łapiński. Sam tłumacz powiedział o Miłości: „ma najmniej tekstu, a przekaz uniwersalny i wzruszy każdego”, http://stl.org.pl/baza-wiedzy/tlumacze-o-sobie/pawel-lapinski (dostęp: 18.10.2020).
} 
„Kocham cię, kiedy to widzisz, i kiedy tego nie widzisz”, „Kocham cię, kiedy jesteś blisko, i kiedy blisko jest awantura”, „Kocham cię, bo jesteś moim dzieckiem, ale nigdy nie będziesz tylko mój". Natomiast w Przyjaźni Archibald poznaje Sama, nowego chłopca w klasie, który „wszystko robi jakoś inaczej". Bohater dochodzi do wniosku, że najbardziej mu się podoba w nowym przyjacielu to, czym się różnią.

Z pewnością książki tego typu zaskoczą uczniów, którzy w kanonie lektur omawianych na lekcjach języka polskiego rzadko znajdują coś wartego ich czasu i uwagi ${ }^{13}$. Wybrane przeze mnie teksty są atrakcyjne ze względu na swoją objętość oraz pozorną łatwość w odbiorze, gdyż operują kodami czytelnymi dla dorosłych i nastolatków. Ich czytanie i omawianie staje się treningiem analizowania sytuacji problemowej, interpretacji zdarzeń fabularnych, myślenia twórczego i kreatywnego. Warto też zauważyć, że umieszczenie jednego zdania lub nawet jego części na stronie sprawia, iż tekst czyta się wolniej, z namysłem. Brak dostępnych internetowych opracowań wpływa z kolei na to, że uczniowie nie są biernymi odbiorcami cudzych przemyśleń. Ponadto przedstawione sytuacje są im bliskie i łatwiej im utożsamić się z Archibaldem, bohaterem Przyjaźni oraz Miłości, odczuwać empatię, utożsamić się z jego doznaniami, przeżywać je jako własne i - co za tym idzie - angażować się w przebieg fabuły. Łatwiej jest im także zrozumieć, że lektura może rozśmieszać, wzruszać, skłaniać do refleksji.

Jako podsumowanie dyskusji na temat książek Desbordes warto zaproponować uczniom, by dopisali do swoich prac fragmenty tych utworów (lub - dla kreatywnych - wymyślili własne sentencje). Następnie utworzylibyśmy publikację interaktywną, którą można by umieścić na stronie szkoły.

\section{Zadania szkoły w dobie zdalnej edukacji}

Ostatnie miesiące roku szkolnego 2019/2020 okazały się wielkim sprawdzianem dla polskiego systemu edukacji. Czy zdanym - będzie można ocenić z perspektywy czasu. Z pewnością niespodziewana konieczność przeniesienia nauczania do wirtualnej rzeczywistości, bez wcześniejszego przygotowania nauczycieli i uczniów, bez odpowiednich narzędzi, spowodowała chaos oraz wiele nieporozumień. Nauczyciele z różnymi umiejętnościami i doświadczeniami przystąpili do nauczania w formie zdalnej, podobnie jak uczniowie, mający różne potrzeby emocjonalne i intelektualne.

Zawieszenie działalności szkół, a następnie wprowadzenie nauczania na odległość pokazało, że do ważnych zadań szkoły należy rozwijanie intelektualnej samodzielności, czyli by uczniowie wiedzieli, czego i jak szukać, jak wybierać, jak łączyć zdobywaną wiedzę z własnym doświadczeniem. Szkoły powinny dawać uczniom możliwość jak najpełniejszego

${ }^{13}$ Marta Rusek $(2012$, 207) zauważyła: „Zmiany kulturowe i technologiczne, dominacja kultury masowej, Internet, sprawiły, że wytworzyły się nowe przyzwyczajenia odbiorcze wobec literatury, do których można zaliczyć - między innymi - nastawienie na fragmentaryzm, niechęć do poddawania się regułom wewnątrztekstowym, odchodzenie od linearności na rzecz struktury hipertekstu, nastawienie na nowość i efektowność". Właśnie dlatego rozbudzanie motywacji do czytania wymaga skomplikowanego systemu działań. 
doświadczania i przeżywania rzeczywistości, poznania różnych punktów widzenia, konfrontacji z odmiennymi przekonaniami, gdyż „piękno naszego zawodu polega na tym, że nigdy nie wiadomo, jaki plon wyda ziarno, które siejemy" (Ripp 2017, 87).

Dlatego właśnie warto uczyć z wykorzystaniem metod rozwijających kreatywność, krytyczne myślenie, współpracę, umiejętność rozwiązywania problemów, przygotowania młodych ludzi do życia w świecie niepewności, świecie zmiennym, coraz bardziej złożonym. Przede wszystkim uczeń musi mieć poczucie sensu podejmowanych działań, musi rozumieć, po co się uczy. Rolą szkoły nie może być wyłącznie uczynienie dzieci mądrymi, ale uczynienie ich mądrymi $i$ dobrymi.

\section{Bibliografia}

Beauvais Clementine, 2017, Pasztety, do boju!, Sęk B. (przeł.), Warszawa.

Black Paul, Harrison Christine, Lee Clare, Marshall Bethan i Wiliam Dylan, 2006, Jak oceniać, aby uczyć?, Warszawa.

Brenifier Oskar, 2017, Uczucia. Co to takiego?, Kamińska-Maurugeon M. (przeł.), Poznań.

Desbordes Astrid, 2016, Miłość, Łapiński P. (przeł.), Warszawa.

Desbordes Astrid, 2019, Przyjaźń, Łapiński P. (przeł.), Warszawa.

Dziewit-Meller A., 2017, Damy, dziewuchy, dziewczyny. Historia w spódnicy, Rusinek J. (il.), Warszawa.

Janus-Sitarz Anna i Nowak Ewa, 2012, Praca domowa ucznia a indywidualizacja nauczania, w: Doskonalenie warsztatu nauczyciela polonisty, Janus-Sitarz A. (red.), Kraków, s. 121-141.

Janus-Sitarz Anna, 2009, Przyjemność i odpowiedzialność w lekturze. $O$ praktykach czytania literatury $w$ szkole. Konstatacje, oceny, propozycje, Kraków.

Janus-Sitarz Anna, 2017, Wstęp, w: Każdy uczeń jest ważny. Indywidualizacja na lekcji języka polskiego, Janus-Sitarz A. (red.), Kraków, s. 11-14.

Kowalczyk Anna, 2018, Brakująca połowa dziejów. Krótka historia kobiet na ziemiach polskich, Frej M. (il.), Warszawa.

Nowak Ewa, 2007, Klasyka w szkole - o modelach pracy z utworami $z$ kanonu literackiego, w: Szkolne spotkania z literatura, Janus-Sitarz A. (red.), Kraków, s. 29-48.

Piquemal Michel, 2012, Sprawiedliwy podziat, w: Bajki filozoficzne. Jak żyć razem?, Braunstein M., Krasicki M. (przeł.), Warszawa, s. 33.

Ripp Pernille, 2017, Uczyć (się) z pasja. Jak sprawić, by uczenie (się) było fascynująca podróża, Manthey E., Musiał W. (przeł.), Słupsk.

Rusek Marta, 2007, Przed monitorem i z książka. Polonistyczna edukacja $w$ dobie multimediów, w: Szkolne spotkania z literatura, Janus-Sitarz A. (red.), Kraków, s. 191-215. 
Rusek Marta, 2012, Kwestia stylu. Refleksje o tożsamości polonisty i stylach nauczania, w: Doskonalenie warsztatu nauczyciela polonisty, Janus-Sitarz A. (red.), Kraków, s. 205-225.

Saint-Exupery Antoine de, 2019, Mały Ksiq̨̇ę, Lemańczyk M. (przeł.), Pląskowski T. (il.), wyd. 2, Warszawa.

Świtała Sabina, 2018, „Oswajanie” nowych technologii na lekcjach języka polskiego, „Polonistyka. Innowacje”, nr 7, s. 153-164.

\section{O Autorce}

Aleksandra Araszkiewicz - doktor nauk humanistycznych, absolwentka filologii klasycznej i polskiej UAM w Poznaniu, nauczycielka, tłumaczka. Ukończyła studia podyplomowe w zakresie psychopedagogiki, oligofrenopedagogiki oraz bibliotekoznawstwa. Obecnie pracuje w Zespole Szkół w Mieście Obrzycko. Uczestniczyła w wielu ogólnopolskich i międzynarodowych konferencjach. Jest autorką przekładu i obszernego opracowania pt. Chrześcijański Terencjusz na scenie (2013). Publikowała artykuły zarówno dotyczące teatru średniowiecznego, jak i wynikające z jej doświadczeń jako nauczycielki języka polskiego. 
